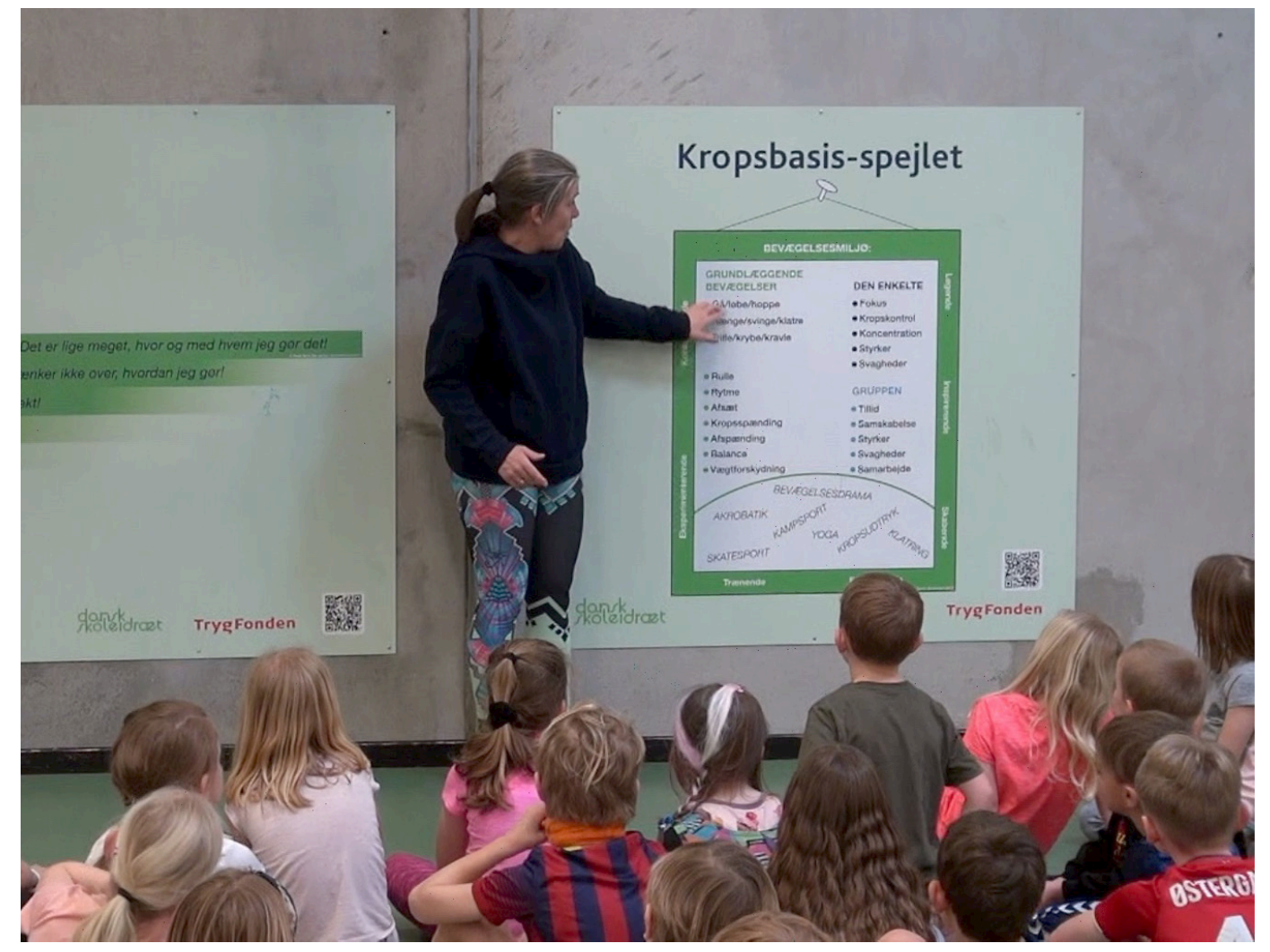

\title{
Når teori i idræt understøtter den praktiske dimension af faget
}

\author{
ANDREAS BOLDING CHRISTENSEN, EMILIE PETERSEN OG \\ MARIE MESSELL
}

I artiklen undersøger vi, hvordan teori kan inddrages i idrætsundervisningen, så det understøtter fagets praktiske dimension. Med udgangspunkt i et undervisningsforløb på læreruddannelsen om teoriintegration i idræt har vi udviklet en didaktisk model, der kan hjælpe idrætslærere med at inddrage teori. Modellen kalder vi for Teoriintegrationsmodellen (TIM). I artiklen udfolder vi modellen og kommer med en række praksisnære eksempler på god inddragelse af teori. Til slut afliver vi en række misforståelser om teori i idræt og opstiller i stedet, hvad vi mener, er mere korrekte forståelser. 


\section{ANDREAS BOLDING CHRISTENSEN}

Cand.scient. Idræt og Sundhed

Lektor, Læreruddannelsen på Fyn,

UCL Erhvervsakademi og Professionshøjskole

abch@ucl.dk

EMILIE PETERSEN

Kandidatstuderende, Idræt og Sundhed, Syddansk Universitet

epete17@student.sdu.dk

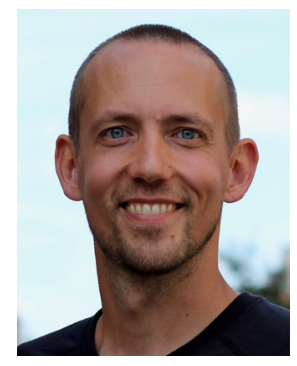

MARIE MESSELL

BSc. Idræt og Sundhed, Cand. Pædagogik Adjunkt, Lærer- og pædagoguddannelsen på Fyn, UCL Erhvervsakademi og Professionshøjskole mame@ucl.dk
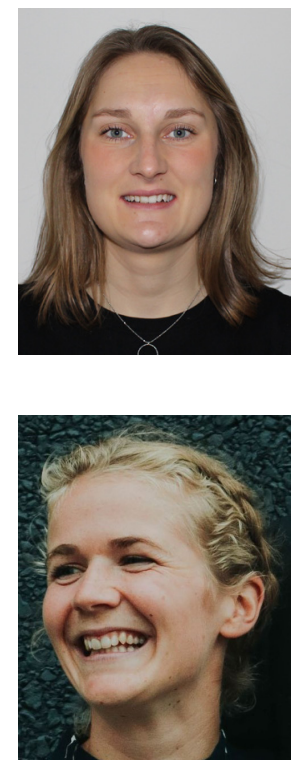

\section{PRAKSISFORTAELING}

Ea og Mathilde fra 2.b står i hallen ved den store muskelmand, der hænger på væggen. Pigerne forsøger efter bedste evne at udtale navne på musklerne og småfniser, når de ikke kan finde ud af det. Samtidig peger de på plakaten og hinanden og taler om, hvor musklerne sidder på dem selv. Louise og Tobias, idrætslærere fra overbygningen, træder ind i hallen, og da Ea og Mathilde ser dem, drøner de ud af hallen.

8.a skal have idræt og samles i starten af lektionen i en halvcirkel ved whiteboardet og projektoren. De har en fast "tjek-in" rutine, hvor de mødes ved tavlen eller en af de modeller, der hænger på hallens vægge. Tobias spørger, hvem der har talt med deres bedsteforældre siden sidst. Flere elever rækker hånden i vejret og en elev uddyber: "Da min farfar havde idræt i skolen, blev de tvunget til at have hvide undertrøjer på til idræt, og de lavede kun sådan noget mærkeligt gymnastik”. En anden elev supplerer: "Ja, det fortalte min morfar også, men det passer jo bare total godt med den der figur om, hvordan idræt var i gamle dage!” 


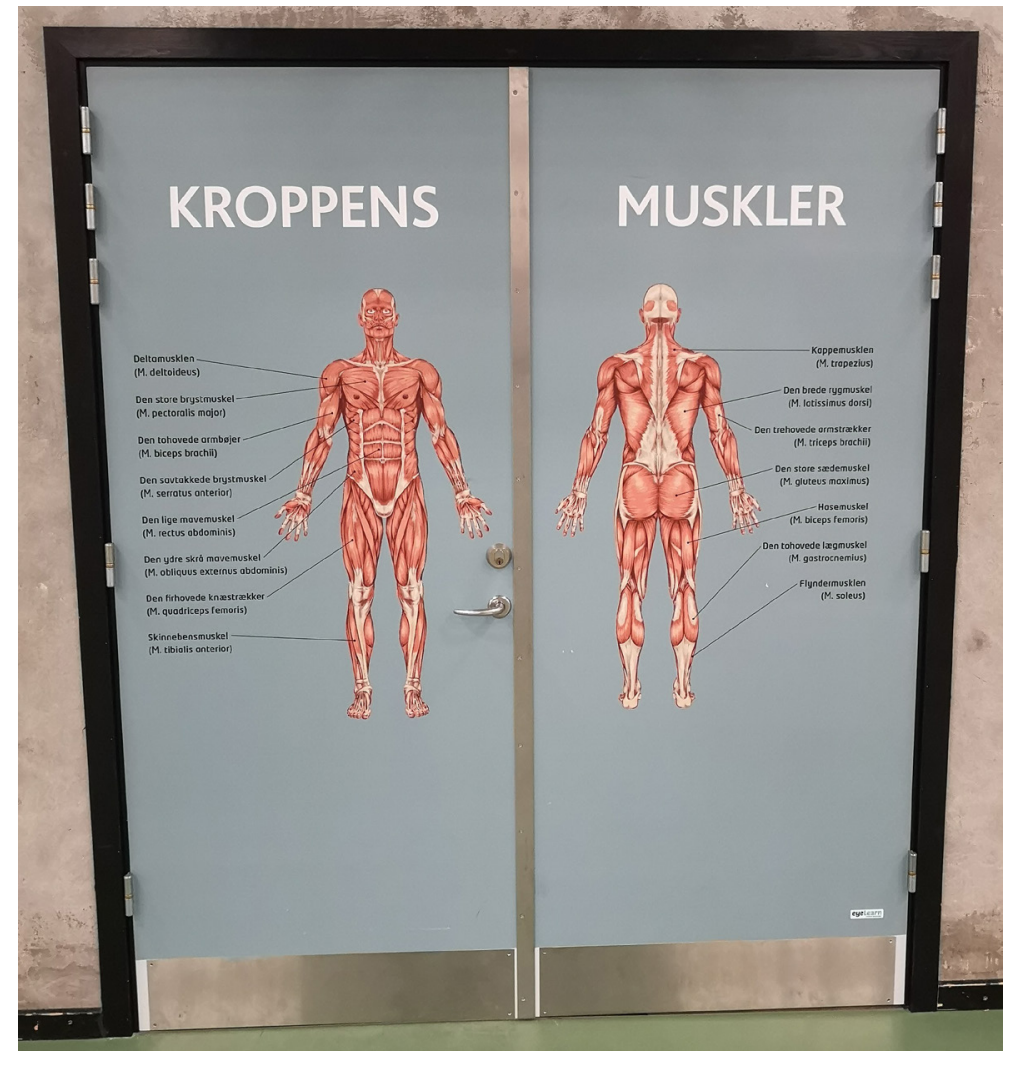

Efter tjek-in siger Tobias: "Tak for indblikket i idrætsundervisningen fra forrige århundrede. Modsat dengang får I nu mulighed for at varme op, som I har lyst, I skal bare bevæge jer rundt på redskabsbanen. Når musikken starter, må I gå i gang!"

Lidt tid senere fader musikken ud, og eleverne samles ved Louise. De puster, smiler og har røde kinder. Louise står ved modellen med kropsbasisspejlet og spørger, hvad de arbejdede med sidst. "Flikflak" siger flere elever i munden på hinanden. "Og hvad er vigtigt for at kunne udføre en flikflak?” spørger Louise. "Man skal være spændstig!" udbryder en af drengene med et fjollet grin. "Ja, det er rigtigt. Det kalder vi også for kropsspænding," siger Louise og peger på begrebet på modellen. Hun beder eleverne snakke med sidemanden om, hvad der er vigtigt, når man skal lave en flikflak. Flere elever imiterer delbevægelser i flikflak og supplerer med forklaringer. Kort efter samler Louise op, og de fastslår i fællesskab, hvad de tre vigtigste begreber og delelementer i flikflak er.

I mellemtiden har Tobias opstillet tre stationer, hvor eleverne kan arbejde med de tre delelementer. Eleverne går i krig med at øve sig og eksperimentere. Efter knap 20 minutter med kropslige udfordringer, glædesudbrud og frustrationer, kalder Tobias eleverne sammen. Her sætter eleverne ord på, hvordan de har arbejdet 
med de tre begreber. En dreng siger: "Jeg kan sgu mærke nu, når jeg laver kropsspænding!”. Tobias spørger, hvad han helt konkret gør. "Øhh, det er lidt svært at forklare," siger drengen, mens han klør sig i håret. En anden dreng byder ind med, at han fokuserer på at spænde i sine muskler, så han ikke "falder sammen”. To andre elever supplerer med deres oplevelser.

Tobias inddeler herefter klassen i grupper og sender dem ud for at arbejde med den færdige flikflak, hvor de på skift bærer hinanden rundt. "Alle skal rundt i en flikflak i dag," råber Tobias, og reaktionerne fra eleverne er alt lige fra "Fuck, hvor fedt," til "Det er jeg altså ikke sikker på, at jeg tør".

Da der er syv minutter tilbage, pifter Tobias til oprydning, og eleverne tømmer halgulvet for redskaber. Klassen mødes ved projektoren, hvor Louise runder af med at fortælle, at eleverne inden næste gang skal snakke med enten deres mor eller far om, hvordan det var at have idræt, da de gik i skole.

På vej over til personalerummet siger Tobias til Louise: "Det er vildt, hvor meget anderledes vores undervisning er nu i forhold til bare for to år siden”. "Ja!" svarer Louise og følger op med: "Det var dælme svært, men nu føles det jo meget nemt. Gad vide hvad vi egentligt gør anderledes?” “Ja, det er et godt spørgsmål," siger Tobias.

\section{FORMÅLET MED ARTIKLEN}

Ovenstående praksisfortælling stammer fra samtaler med de to idrætslærere, Louise og Tobias, samt observationer fra deres idrætsundervisningen. De har gennem de sidste par år ændret deres måde at undervise på, og derfor har vi været på besøg hos dem for at finde inspiration til vores idrætsundervisning på læreruddannelsen i Odense. Som det ses i slutningen af praksisfortællingen, har Louise og Tobias taget nogle mere eller mindre bevidste valg og underviser i dag mere systematisk og varieret med teori, fagbegreber og viden i idrætsfaget. For dem er det nu blevet en del af deres rutiner og handlerepertoire, som er med dem, når de forbereder, gennemfører og evaluerer deres undervisning. Vi er inspirerede af deres praksis og vil i denne artikel mere generelt undersøge spørgsmålet:

\section{Hvordan kan teori inddrages i idræetsundervisningen, så det understøt- ter fagets praktiske dimension?}




\section{ARTIKLENS OPBYGNING}

1) Først definerer vi centrale begreber, som vi bruger i artiklen. 2) Dernæst argumenterer vi for, hvorfor det overhovedet er relevant at sætte fokus på og beskæftige sig med teori i idrætsundervisningen. 3) Efterfølgende præsenterer og uddyber vi en konkret model, hvis funktion er at hjælpe idrætslærerstuderende og idrætslærere til at reflektere over og handle på, hvordan teori kan inddrages i undervisningen, så det understøtter fagets praktiske dimension. 4) Til slut afliver vi nogle gængse misforståelser om teori i idrætsundervisningen og vender disse til - i vores optik mere korrekte forståelser.

\section{LAD OS LIGE FÅ GREB OM BEGREBERNE}

Praksis, teori, fagbegreber og teorïntegration er nøglebegreber i denne artikel. Derfor vil vi kort redegøre for, hvad vi mener med disse begreber i relation til idrætsundervisning.

Praksis forstår vi som de kropslige aktiviteter, eleverne skal præsenteres for og have erfaring med på egen krop i idrætsundervisningen. Aktiviteterne knytter sig typisk til et af fagets praksisområder fx redskabsaktiviteter, boldspil eller dans og udtryk.

Teori forstår vi som de fagbegreber, eleverne præsenteres for, skal have viden om og kunne anvende i idrætsundervisningen. I Fælles Mål kan man fx læse, at eleverne efter 2. klasse bl.a. skal have viden om tid og kraft, balance, regler, samarbejdsmåder, følelser samt hvile- og arbejdspuls. Som det fremgår af eksemplerne, er der ikke som sådan tale om samlede teorier, men snarere enkelte fagbegreber. Disse udspringer af idrætsteorier inden for naturvidenskab, samfundsvidenskab og humaniora. Derfor vil vi - inspireret af Piaster (2020) - bruge teori og fagbegreb som synonymer.

Teori kan integreres i den praktiske idrætsundervisning på en måde, hvor teorien understøtter praksis. Inspireret af Knudsen og Seelen (2019) kalder vi dét for teoriintegration. Praksisfortællingen med Louise og Tobias illustrerer netop, hvordan teori på forskellige måder kan integreres i det praktiske idrætsrum i hallen.

Inden vi fordyber os i, hvordan idrætslærere kan arbejde med teoriintegration, vil vi kort argumentere for, hvorfor det overhovedet er relevant at arbejde med teoriintegration i idræt. 


\section{HVORFOR OVERHOVEDET SATTE FOKUS PÅ TEORI I IDRAT?}

\section{Et tilbageblik på de seneste 15 år}

En rapport fra EVA (2004) viser, at teori i idrætsundervisningen ikke er højt prioriteret blandt idrætslærere. Når lærerne inddrager teori, er det sjældent forberedt, og der er i højere grad tale om, at der bliver improviseret i selve undervisningssituationen.

I 2012 er det samme billede gældende, hvor SPIF-rapporten (Seelen \& Munk, 2012) viser, at prioriteringen af teori er uændret. Lærere og elever giver udtryk for, at teoriinddragelse i idræt ikke må gå ud over det praktiske, og at teori er uforeneligt med at have det sjovt. Når lærerne inddrager teori, så er det primært fysiologi og anatomi.

I 2015 indføres afgangsprøven i idræt, og her kommer det teoretiske yderligere i fokus, da eleverne bl.a. afprøves i idrætsfaglig viden. En undervisning, der afspejler prøven, bør derfor bære præg af refleksion og analyser af, hvordan teori og praksis kan integreres (Bertelsen et al., 2016).

Den seneste SPIF-rapport (Seelen et al., 2018) viser, at teoriforståelsen stadig er uændret. Det er forsat fysiologi og anatomi, der fylder mest - nu blot suppleret med teori om regler og boldspilstyper. Holdningen til elevers teoretiske færdigheder har dog ændret sig, da flere idrætslærere nu vurderer, at disse er vigtige. Flere lærere vurderer også, at eleverne rent faktisk udvikler teoretiske færdigheder. Samtidig vurderer lærerne, at de har behov for efteruddannelse i metoder til integration af teori og praksis.

\section{Idrætsfagets dannelsespotentiale - teoriintegration som ét væsentligt element}

Fagformålet i idrætsfaget lægger op til dannelse af den hele elev ved både at vægte kropslige, idrætslige, sociale og personlige kompetencer. Rostbøll (2019) fremhæver dog, at idrætsfaget ikke lever op til dette dannelsespotentiale. Dét begrunder hun med, at idrætslærerne i Danmark i lav grad vægter kompetenceområdet Idrættens kulturer og relationer, som vurderes til at indeholde det største dannelsespotentiale. Lærerne vægter i højere grad kompetenceområderne Alsidig idrætsudøvelse samt Krop, træning og trivsel (Rostbøll, 2019). Potentielle dannelseselementer i idrætsfaget kunne fx være: samarbejde, identitet, normer, værdier eller glæde. Det illustrerer dermed, at dannelse i idræt er langt mere end kropslige kompetencer, og Rostbøll (2019) fremhæver refleksion som en central del af arbejdet med dannelseselementerne. Refleksion i idrætsfaget er også af andre blevet fremhævet som vigtigt ift. at opnå ny erkendelse og læring (Knudsen \& Seelen, 2019; Peitersen \& Rønholt, 2008; Rostbøll, 2019). Vi argumenterer i denne artikel for, at teori er vigtigt ift. at kvalificere disse refleksioner og derigennem øge fagets lærings- og dannelsespotentiale. I dette argument læner vi os op ad Hastrup, der 
skriver: "Teorier står ofte som enten åbenbaringer eller uhyrer (...). Faktisk er de jo helt udramatiske forslag til, hvordan noget kan forstås." (Hastrup ifølge Peitersen og Rønholt, 2008). I tråd med dette mener vi, at teoriintegration kan være med til at åbne elevernes øjne for nye perspektiver samt måder at forstå og anskue idræt på. Teoriintegration er derfor ét vigtigt element (blandt andre) ift. at styrke fagets (ud)dannelsesdimension. Derudover viser dansk forskning, at teoriintegration skaber øget deltagelse og motivation blandt elever, der ikke tidligere har været motiveret for idræt (Hansen, 2017; Knudsen, 2017). Dette er væsentligt ift. at give alle elever mulighed for at opleve idrætsfagets mange unikke dannelseselementer.

\section{TEORIINTEGRATIONSMODELLEN}

På læreruddannelsen i Odense har vi i et undervisningsforløb sammen med de idrætslærerstuderende undersøgt, hvordan teori kan integreres, så det understøtter den praktiske dimension af faget. Forløbet har vi opbygget med inspiration fra Dales tre kompetenceniveauer. K1-niveauet handler om at gennemføre undervisning, K2 om at planlægge og evaluere undervisning og $\mathrm{K}_{3}$ om at kommunikere og konstruere didaktisk teori (Peitersen \& Rønholt, 2008). På K3-niveau har de

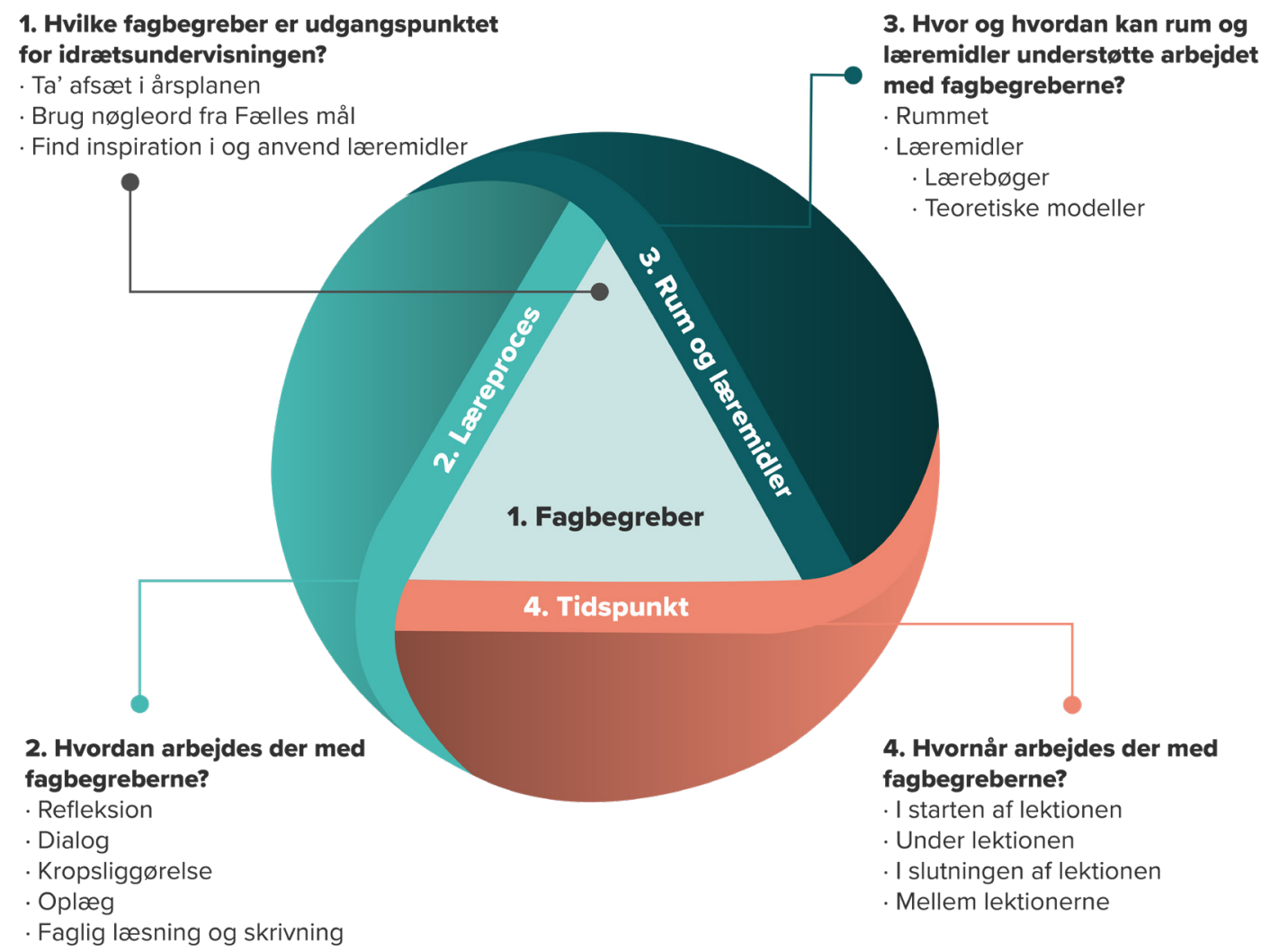

Figur 1: Teoriintegrationsmodellen 
studerende udviklet didaktiske modeller for, hvordan teori kan integreres i idræt. Disse modeller (i alt 15 stk.) har vi analyseret, og ud fra vores analyse har vi udviklet Teoriintegrationsmodellen (TIM).

Modellen tilbyder med sine fire didaktiske spørgsmål nogle grundlæggende holdepunkter, der danner udgangspunkt for refleksion og handling i forbindelse med teoriintegration i idræt. Modellen er selvfølgelig en forenkling af den komplekse opgave, der ligger i at inddrage teori i idræt. Forenklingen er dog helt bevidst og muliggør, at modellen bliver brugbar i idrætslærerens daglige arbejde. Målet er derfor, at modellen er anvendelsesorienteret, så den ikke kun făr idrætslæreren til at reflektere, men også til at handle. I det følgende uddyber vi alle modellens delelementer.

\section{Fagbegreber - Hvilke fagbegreber er udgangspunktet for idræetsundervisningen?}

I dette afsnit vil vi præsentere tre trin til at udvælge fagbegreber. Når vi skriver udgangspunktet for idrætsundervisningen, er det med afsæt i en antagelse om, at idrætslærerens møde med eleverne er med afsæt i et fagligt indhold og nogle faglige mål. Den udvælgelse er omdrejningspunktet for dette didaktiske spørgsmål, som har til hensigt at gøre det nemmere for idrætslæreren at foretage valg om, hvilke fagbegreber der skal være udgangspunktet for mødet med eleverne. Vi foreslår følgende tre trin:

\section{Trin 1: Ta' afsæt i årsplanen}

Dels kan der være vigtige fagbegreber noteret i årsplanen, dels fortæller årsplanen noget om forløbets varighed. Varigheden har betydning for hvor mange og hvor komplekse fagbegreber, der kan være udgangspunkt for undervisningen.

\section{Trin 2: Brug nøgleord fra Fælles Mål}

Der kan være inspiration til udvælgelse af fagbegreber i Fælles Mål, og ligeledes kan læseplanen i faghæftet (Undervisningsministeriet, 2019) give yderligere inspiration.

\section{Trin 3: Find inspiration i og anvend læremidler}

Læremidler tilbyder også inspiration til valg af fagbegreber, men til forskel fra Fælles Mål, indeholder læremidler ofte uddybninger og beskrivelser af fagbegreber. Det kunne fx være Tjek på idræt (Hedeskov \& Gade, 2015), (Be)greb om idræt (Christensen \& Svendsen, 2019), Idræt på hjernen (Knudsen, 2015), Løb, spring og kast-dugen (Piaster et al., 2019) eller Sundhedsdugen (Skoleidræt, 2020). Disse læremidler kan give fagbegreberne noget tyngde, så både lærere og elever kan forstå, udfolde og anvende fagbegreberne i idrætsundervisningen. 

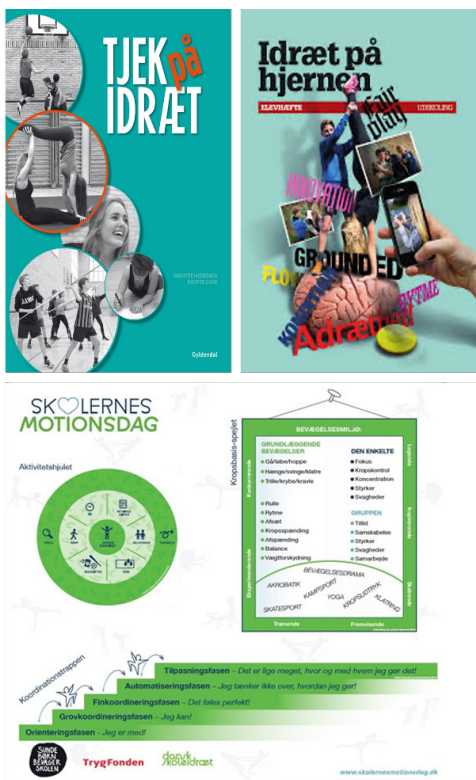

REDSKABSAKTIVITETER
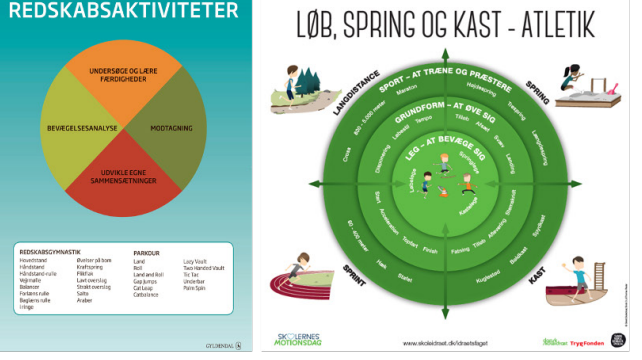

IDRET OG SUNDHED

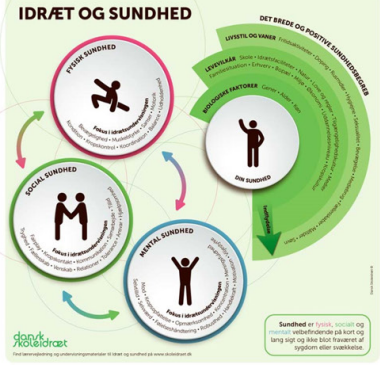

DANS OG UDTRYK

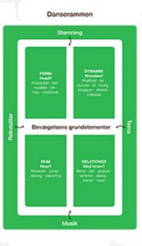

SKOLERNES

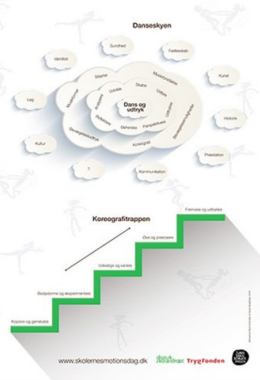

Billede 2: Eksempler på forskellige læremidler

\section{Læreproces - Hvordan arbejdes der med fagbegreberne i idræetsundervisningen?}

I dette afsnit vil vi præsentere forskellige processer til, hvordan der kan arbejdes med fagbegreber i idrætsundervisningen. Eleverne skal i idrætsfaget arbejde med talesprog og skriftsprog, og derfor vil vi både uddybe mundtlige og skriftlige samt kropslige perspektiver på integration af fagbegreber i undervisningen. Vi vil specifikt komme omkring fagsprog gennem refleksion, dialog, kropsliggørelse og oplæg samt faglig læsning og skrivning. En proces udelukker selvfølgelig ikke de andre, og processerne vil ofte supplere og kvalificere hinanden, som når fx kropsliggørelse af teori efterfølges af faglig refleksion eller dialog om oplevelserne. Processerne giver læreren mulighed for at vurdere elevernes viden om og anvendelse af fagbegreberne.

\section{Gennem refleksion}

Peitersen og Rønholt (2008) fremhæver, at udviklingen af elevers kropslige, idrætslige, sociale og personlige kompetencer (idrætsfagets formål) bl.a. sker gennem refleksion og deling af egne refleksioner. Flere anerkendte læringsteoretikere betoner også refleksionens rolle i læreprocesser. Fx fremhæver Illeris (2015) med henvisning til Kolbs læringscyklus, hvordan refleksion og begrebsliggørelse indgår som centrale elementer i en læreproces. I idrætsundervisningen kan refleksion med fagbegreber fx stimuleres gennem strukturerede refleksionsspørgsmål. I et forløb med redskabsaktiviteter kan læreren fx bede eleverne om individuelt at reflektere over, hvad der skal til for at holde balancen i en håndstand. Herefter deler 
eleverne deres refleksioner, og fagbegrebet kropsspænding kan kobles til elevernes umiddelbare refleksioner og derigennem skabe en øget forståelse og et nyt fokuspunkt i det videre arbejde med håndstanden. På den måde bruges refleksion - med og uden fagbegreber - til at skabe ny erkendelse.

\section{Gennem dialog}

Idrætsundervisning er ofte baseret på gruppearbejde (Peitersen \& Rønholt, 2008), hvorfor dialog som metode kan ses som særlig oplagt. Dialog giver mulighed for at forstå nye perspektiver og sammenhænge (Oettingen, 2018), og elevernes bevidsthed og erkendelse bliver udfoldet og udfordret, når det bliver delt i en dialog (Thingholm, 2020). I idrætsundervisningen kan dialog med fagbegreber fx være, når grupper arbejder med aktivitetsudvikling og ved hjælp af begreber fra aktivitetshjulet (Hovgaard, 2017) diskuterer, hvilke kategorier de vil justere på i deres aktivitet. Her anvender eleverne fagbegreber som retningslinjer, relationer, rum, rekvisitter, krop, tid og energi.

Undervejs undersøger eleverne sammenhænge ved $\mathrm{fx}$ at diskutere, hvordan en ændring i rummet påvirker andre kategorier som tid og krop. Eleverne bliver måske i tvivl om, hvad der egentlig menes med kategorien energi, og undersøger sammen begrebets betydning. På den måde bruges dialogen til at undersøge betydninger og sammenhænge mellem fagbegreber, og elevernes hverdagssprog og tavse viden udfordres og udfoldes.

\section{Gennem kropsliggørelse}

Dialog og refleksion i idrætsundervisningen bruges ofte til at sætte fagbegreber på kropslige erfaringer - eller sagt på en anden måde: sætte ord på bevægelse. Omvendt kan man også sætte bevægelse på ord gennem kropsliggørelse af fagbegreber, som skaber en handlingsorienteret tilgang til at forstå fagsproget. En handlingsorienteret tilgang tager afsæt $\mathrm{i}$, at kognitive processer bliver meningsfulde via handling (Gallagher, 2017). I idrætsundervisningen kan eleverne få sansemotoriske, følelsesmæssige og sociale erfaringer med fagbegreberne og dermed forstærke forståelsen af fagbegreberne (Madsen \& Aggerholm, 2020). Det kunne fx være, når eleverne arbejder med fagbegreber som kredsløb og puls. Her skal eleverne kropsliggøre kredsløbet ved at løbe igennem en bane af redskaber, der illustrerer blodets vej gennem hjertet og kroppen. Samtidig kan eleverne opleve, at jo hurtigere, der løbes gennem banen, jo højere bliver pulsen, og jo hurtigere løber blodet rundt i kroppen. På den måde kan kropsliggørelse af fagbegreber gøre svære og abstrakte fagbegreber mere konkrete og meningsfulde. 


\section{Gennem oplæg}

Oplæg i idrætsundervisningen kan både være i form af lærer- og elevoplæg. Et lærerstyret oplæg giver mulighed for, at eleverne bliver præsenteret for en fyldestgørende og præcis information om indholdet af undervisningen samt hvilke fagbegreber, der skal arbejdes med (Høegh, 2018). Et oplæg i idræt kan desuden have den fordel, at eleverne hurtigt kan "komme i gang med handling" (Peitersen \& Rønholt, 2008). En ulempe ved lærerstyrede oplæg er, at eleverne kan miste koblingen mellem fagbegrebet og deres kropslige oplevelser. I denne sammenhæng kan fagbegreberne virke tomme og fremmede (Hansen, 2020). Lærerstyrede oplæg kan altså være en hurtig og let måde, hvorpå fagbegreber kan integreres i idrætsundervisningen. Sådanne oplæg kan dog med fordel suppleres med andre processer, som i højere grad hjælper eleverne med at koble begreb og bevægelse.

Elevoplæg er ligeledes en måde, hvorpå fagbegreber kan integreres. I forberedelsen af oplægget bliver eleverne nødt til at tilegne sig fagsprog for at kunne formidle emnet videre til klassekammerater. I idrætsundervisningen kan integration af fagbegreber gennem elevoplæg fx være i et forløb med temaet fairplay. Her skal eleverne formidle viden om fairplay i forskellige idrætsgrene, mens de kropsliggør situationer, hvor fairplay enten kommer eller ikke kommer til udtryk.

\section{Gennem faglig læesning og skrivning}

Skriftlighed - herunder både læsning og skrivning - rummer mange af de samme muligheder, som når eleverne arbejder med fagsprog mundtligt.

Fordelene ved at lade eleverne læse før (eller i) idrætsundervisningen er, at teksterne kan understøtte arbejdet med fagsprog, fordi teksterne præsenterer, hvordan fagbegreberne skal bruges i forbindelse med et bestemt indholdsområde eller tema.

Fordelen ved at lade eleverne udtrykke sig skriftligt er, at det i særlig grad træner brugen af fagsprog frem for hverdagssprog. Skriftsprog har desuden den egenskab, at det fungerer over tid og sted (Mulvad, 2012). Når eleverne formulerer sig skriftligt, har det derfor den fordel, at det også kan bruges i næste idrætstime. Ligeledes kan tekster og modeller findes frem igen på et senere tidspunkt.

I idræt kan skriftlighed i form af læsning fx komme til udtryk i et forløb med løb, spring og kast, hvor eleverne som lektie læser kapitlet OL: hurtigere, højere og stærkere fra bogen (Be)greb om idræt (Christensen \& Svendsen, 2019). Skrivning kan fx komme til udtryk i et forløb med dans og udtryk, hvor eleverne på skrift skal beskrive en koreografi ud fra danserammens (Svendsen \& Skoleidræt, 2018) centrale begreber: form, dynamik, rum og relationer. På den måde bliver fagsprog eksplicit integreret i idrætsundervisningen, og teksterne vil senere kunne tages i brug igen, fx i forbindelse med afgangsprøven i idræt. 


\section{Rum og læremidler - Hvor og hvordan kan rum og læremidler understøtte arbejdet med fagbegreber?}

I dette afsnit vil vi præsentere, hvordan indretning af hallen som faglokale samt brug af læremidler - herunder lærebøger og modeller - kan understøtte integrering af fagbegreber i idrætsundervisningen.

\section{Rummet}

Idrætsundervisningen foregår oftest i hallen eller på sportspladsen. Rummene, hvori idrætsfaget praktiseres, kan betragtes som faglokaler. Et faglokale skal her forstås som et rum beregnet til undervisning i et skolefag, der kræver særlige hjælpemidler. Mange hjælpemidler i idræt understøtter den praktiske dimension af faget som fx bolde, kegler, overtrækstrøjer, springredskaber, kort og kompas, spyd og kugler, musikanlæg, m.m. Modsat mangler der ofte hjælpemidler til at understøtte den mere teoretiske dimension af faget fx bøger, tavler, papir, skriveredskaber, IPads, projektor og lignende. Inden for arkitekturpsykologi bruger man begrebet affordance til at beskrive, hvad et rum "inviterer til" (Andkjær, 2010). I dette tilfælde kan man sige, at idrætsfagets faglokaler primært inviterer til bevægelse og i langt mindre grad til synliggørelse af fagbegreber. Rummets affordance kan derfor spænde ben for lærerens arbejde med at integrere fagbegreber, og derfor er der et potentiale i at "geare" rummet til teoriintegration. I fortællingen i starten af denne artikel gav vi et eksempel på et idrætsfaglokale, som er gearet til teoriintegration. Særligt de teoretiske modeller på væggene bidrager til at gøre fagbegreberne synlige, men også hjælpemidler som whiteboard og projektor indgår i lokalet. På den måde inviterer rummet i højere grad til både at arbejde med kropslige aktiviteter og udvikling af fagsprog.

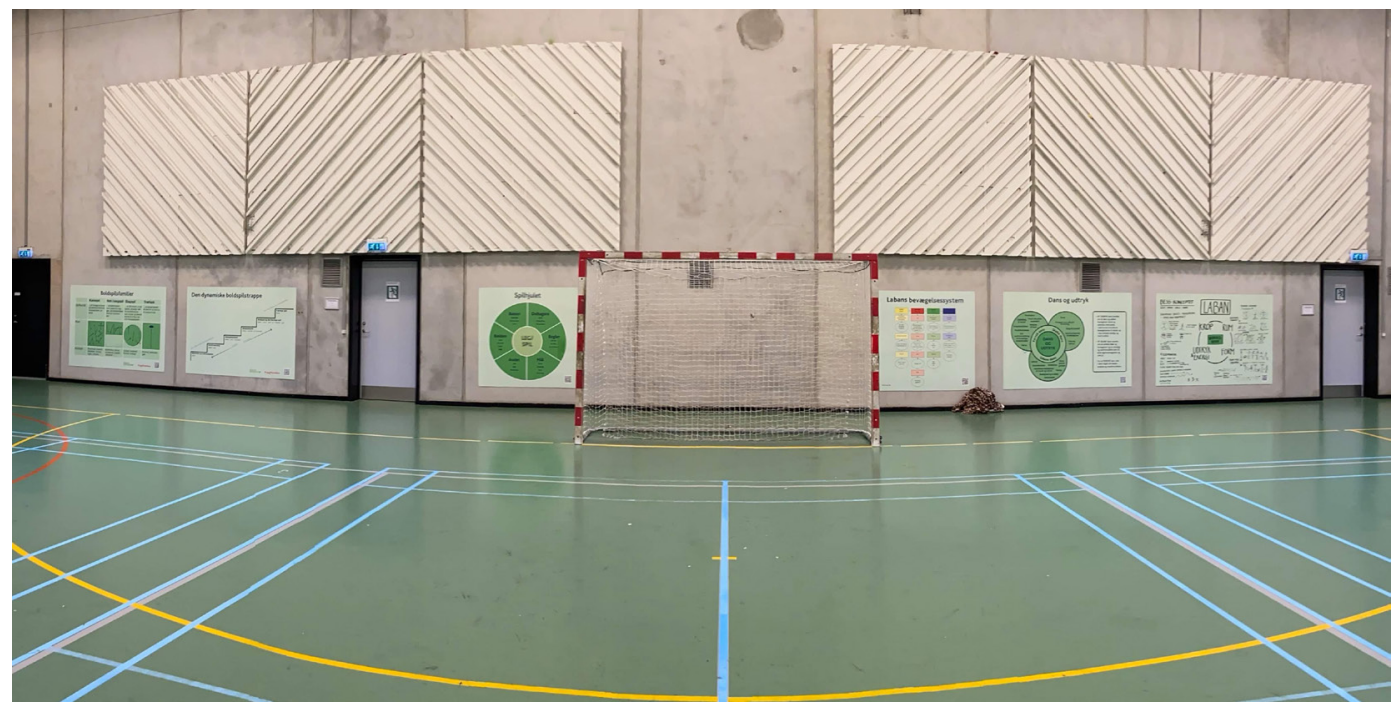

Billede 3: Forskellige modeller i idrætshallen på Holluf Pile Skole i Odense. 


\section{Læremidler}

Læremidler kan bruges til integration af fagbegreber i idrætsundervisningen. Her har vi valgt at beskrive, hvordan lærebøger og modeller kan anvendes.

\section{Lærebøger}

I idrætsundervisningen i Danmark er der ikke tradition for at anvende lærebøger til eleverne (Svendsen, 2012). Udvalget at lærebøger i idræt er derfor heller ikke stort. Lærebøger i idræt rummer et potentiale ift. at arbejde med fagbegreber. Lærebogens fysiske form skaber nye muligheder, som kan supplere den lærercentrerede og mundtlige tradition i idræt (Knudsen, 2017), og giver derfor eleverne mulighed for selv at udforske fagbegreberne. Det er oplagt, at eleverne arbejder med lærebøger som lektie mellem to undervisningsgange, men bøgerne er også velegnede til at skabe refleksion og dialog i undervisningen. Knudsen (2017) peger netop på vigtigheden af at rammesætte brugen af lærebøger, så der opstår et samspil mellem lærebøger og idrætsfagets praktiske dimension. Derudover kan lærebøger også medbringes i den udendørs idrætsundervisning (hvis vejret tillader det), hvor det kan være svært at anvende andre hjælpemidler som fx projektor og whiteboard. Eksempler på lærebøger i idræt er (Be)greb om idræt til udskolingen (Christensen \& Svendsen, 2019) og til indskolingen (Christensen og Svendsen, under publicering), Idræt på hjernen (Knudsen, 2015) og Tjek på idræt (Hedeskov \& Gade, 2015).

\section{Teoretiske modeller}

På mange skoler begynder modeller at finde vej til idrætsfaglokalet. Nationalt Videncenter, KOSMOS, har samlet og udviklet en række idrætsdidaktiske modeller til fri download. Dansk Skoleidræt har udgivet en række duge med teoretiske modeller, der er målrettet eleverne. Her kan du finde dansedugen, kropsbasisdugen, boldspilsdugen, løb, spring og kast-dugen og senest sundhedsdugen. Dugene kan hænges op på væggen i hallen eller kastes ud på græsset på sportspladsen og bidrager på den måde til at gøre fagbegreberne synlige og nærværende i undervisningen - indendørs og udendørs. De inviterer til faglig refleksion og dialog, som kan være lærerinitieret, men giver også mulighed for at eleverne selv kan stoppe op ved plakaterne og bliver nysgerrige på fagbegreberne, som i eksemplet med Ea og Mathilde fra 2.b i den indledende praksisfortælling. Modellerne kan vha. små modificeringer bruges på alle klassetrin. Fx kan plakaten af "den store muskelmand" redidaktiseres, så man i undervisningen bruger de danske ord for musklerne i steder for de for de latinske betegnelser, der står på plakaten. 


\section{Tidspunkt - Hvornår arbejdes der med fagbegreberne i idrætsundervisningen?}

I dette afsnit vil vi præsentere, hvornår der kan arbejdes med fagbegreber igennem de beskrevne processer og med inddragelse af læremidler. Arbejdet med fagbegreber kan ske både i starten, undervejs og i slutningen af lektionen, men også mellem lektionerne. Et tidspunkt udelukker selvfølgelig ikke de andre tidspunkter. Engell og Hansen (2009) giver et bud på, hvordan der kan arbejdes med forskellige refleksionsopgaver før, under og efter en lektion. Inspireret af dette vil vi beskrive, hvordan arbejdet med fagbegreber kan tilrettelægges tidsmæssigt, så det også giver mulighed for at vurdere elevernes viden om og anvendelse af fagbegreberne.

\section{I starten af lektionen}

Arbejde med fagbegreber i starten af idrætsundervisningen retter elevernes opmærksomhed mod lektionens faglige indhold. Hensigten er at skabe et fælles fundament, som undervisningen efterfølgende kan tage afsæt i. Det kan fx være, når eleverne præsenteres for temaet tillid i et forløb med redskabsaktiviteter. Her kan en indledende refleksion over fagbegreber som tillid, relationer og ansvar rette elevernes fokus mod netop dette, når de efterfølgende skal springe og være modtagere for hinanden. På den måde bliver elevernes opmærksomhed inden aktivitetsstart rettet mod at opbygge tillidsfulde relationer, og eleverne bliver bevidstgjorte om deres ansvar som både springer og modtager. Allerede fra start styres fokus mod udvalgte aspekter af det, der skal til at foregå i resten af lektionen.

\section{Under lektionen}

Arbejde med fagbegreber undervejs i idrætsundervisningen giver i særlig grad mulighed for at veksle mellem at sætte ord på bevægelse og bevægelse på ord. Konkret kan det fx gøres gennem timeouts, hvor læreren "pauser" den givne aktivitet og skaber tid og rum til at fokusere på udvalgte fagbegreber. En timeout kan enten være planlagt på forhånd eller tages i situationen, hvis der fx er brug for en (kropslig) pause, eller hvis der opstår noget interessant, som knytter sig til undervisningens faglige indhold. Det kan fx være i et kropsbasisforløb, hvor eleverne arbejder med kampsportsinspirerede bevægelser. En elev, der længe har øvet rullefald, udbryder: "Nu behøver jeg ikke længere tænke, når jeg ruller, nu gør jeg det bare!" Læreren kan her lave en timeout og bede eleverne reflektere over, hvor på koordinationstrappen (Høj \& Skoleidræt, 2017) denne elev er. De kommer sammen frem til, at eleven er nået til automatiseringsfasen. Læreren kan også bede eleverne diskutere, hvordan eleven kan nå næste trin; tilpasningsfasen. Her kommer eleverne frem til, at eleven i det videre arbejde med rullefaldet kan eksperimentere med forskellige underlag og overflader og forskellige former for tilløb og afsæt. Fokus 
rettes på den måde mod udvalgte dele af det, der foregår i lektionen, og læreren hjælper i timeouten eleverne med at knytte fagbegreber til dette.

\section{I slutningen af lektionen}

Arbejde med fagbegreber i slutningen af idrætsundervisningen retter elevernes opmærksomhed mod det, der har foregået i lektionen. Afslutningen kan fx have opsummerende eller uddybende karakter. Den kan også give mulighed for at stille spørgsmål. En afsluttende samtale giver desuden læreren mulighed for vurdere, hvilken forståelse eleverne har for de fagbegreber, der har været udgangspunkt for lektionen. Det kan fx være i et forløb om sundhed, hvor eleverne arbejder med det brede positive sundhedsbegreb. Her kan læreren til slut i undervisningen spørge eleverne: "Hvad har I lært om sundhed i dag?" Her vil det ud fra elevernes udtalelser være muligt for læreren at vurdere, om eleverne har forstået, at det brede og positive sundhedsbegreb ikke kun handler om fysisk sundhed, men også psykisk og social sundhed. Fokus i slutningen af lektionen tager således afsæt i de fagbegreber, der er arbejdet med i løbet af lektion.

\section{Mellem lektionerne}

Arbejde med fagbegreber mellem idrætslektioner handler oftest om at sætte fokus på de fagbegreber, der skal arbejdes med i den kommende undervisning. Som lektie kan eleverne fx læse fagtekster fra lærebøger, nedskrive deres forforståelse af udvalgte begreber eller forberede et kort elevoplæg. Lektien kan også have mere dialogisk karakter. Fx kan eleverne i et forløb med temaet idrættens historie blive bedt om at snakke med deres forældre eller bedsteforældre om, hvordan idræt foregik i deres skoletid. Arbejdet med fagbegreberne mellem idrætslektionerne kan også tage udgangspunkt i at arbejde videre med de fagbegreber, eleverne har været igennem i foregående lektion. Fx kan lektien være en kropslig opgave i et forløb om idrætten i samfundet, hvor eleverne med afsæt i deres tilegnede viden fra en idrætslektion får til opgave at afprøve en af lokalområdets idrætsmuligheder. Det er vigtigt, at der i den følgende idrætsundervisning skabes sammenhængen mellem det, eleverne har arbejdet med som lektie, og forløbets centrale fagbegreber. I dette eksempel kunne centrale fagbegreber være tid, rum, relationer og energi. Lektier i afslutningen af et forløb hos udskolingselever kan også være i form af skriftlige produkter af evaluerende karakter. Det kan fx være i et forløb med roller $i$ boldspil, hvor eleverne udvælger centrale fagbegreber og kobler dem til forskellige, interessante situationer, der er opstået undervejs i forløbet. Fx når en elev beskriver sine oplevelser og udfordringer som målmand i et spil floorball og kobler oplevelserne sammen med begreber som overblik og mod. De skriftlige evalueringer kan eleverne bruge som inspiration til afgangsprøven i idræt. 


\section{(MIS)FORSTÅELSER OM TEORI I IDRAETSUNDERVISNINGEN}

Til sidst vil vi udtrykke vores holdning til teori i idrætsundervisningen ved at præsentere en række misforståelser, som vi vender til en mere - i følge os - korrekt forståelse. Til venstre i oversigten nedenfor kan man se misforståelserne. Misforståelserne tager afsæt i nogle gængse holdninger og opfattelser, som vi er stødt på ved læsning af undersøgelser, forskning, litteratur og egne erfaringer fra praksis og uddannelse. Til højre har vi formuleret vores forståelse og uddybet den. Det er et udtryk for vores holdning til teori i idrætsundervisningen og er værdigrundlaget for Teoriintegrationsmodellen.

\begin{tabular}{|c|c|}
\hline Misforståelser & Forståelser \\
\hline Teori er langhåret og tørt & $\begin{array}{l}\text { Teori kan være spændende og motiverende } \\
\text { Teori er bare et udramatisk forslag til, hvordan en idrætspraksis kan forstås. } \\
\text { Læreren kan hjælpe sig selv og sine elever ved at omsætte teori til konkrete } \\
\text { fagbegreber. Fagbegreberne giver eleverne mulighed for at få øje på nuancer, } \\
\text { forstå kropslige oplevelser, samtale om og diskutere praksiserfaringer. }\end{array}$ \\
\hline $\begin{array}{l}\text { Man skal ikke arbejde med } \\
\text { teori i indskolingen }\end{array}$ & $\begin{array}{l}\text { Man skal arbejde med teori på alle klassetrin } \\
\text { Idræt er et fag på niveau med skolens andre fag, og derfor arbejder man selv- } \\
\text { følgelig med færdigheder og viden gennem hele skoletiden. Det giver mulighed } \\
\text { for at arbejde med progressionen fra enkle fagbegreber til mere komplekse } \\
\text { fagbegreber. Forudsætningen for at arbejde med progression er, at læreren gør } \\
\text { sig overvejelser om, hvilke fagbegreber eleverne har arbejdet med tidligere. }\end{array}$ \\
\hline $\begin{array}{l}\text { Teori "går ud over" } \\
\text { den praktiske del af } \\
\text { idrætsundervisningen }\end{array}$ & $\begin{array}{l}\text { Teori og praksis er hinandens forudsætninger } \\
\text { God idrætsundervisning er mere end højt aktivitetsniveau. Det er også at } \\
\text { integrere teori, som på den ene side muliggør refleksion over praksis og på den } \\
\text { anden side muliggør at arbejde med teorien i praksis. På den måde kvalificerer } \\
\text { teorien den praktiske dimension af faget. }\end{array}$ \\
\hline $\begin{array}{l}\text { Teori i idrætsfaget handler } \\
\text { om anatomi og fysiologi }\end{array}$ & $\begin{array}{l}\text { Teori i idrætsfaget trækker på mange vidensområder } \\
\text { Teori i idrætsfaget handler OGSÅ om anatomi og fysiologi, hvilket udspringer } \\
\text { fra det naturvidenskabelige område. Men idrætsfagets spændvidde er meget } \\
\text { bredere og trækker også på teorier fra det humanistiske og samfundsvidenska- } \\
\text { belige område såvel som de mere fagspecifikke teorier. }\end{array}$ \\
\hline $\begin{array}{l}\text { Teori skal præsenteres af } \\
\text { læreren }\end{array}$ & $\begin{array}{l}\text { Teori præsenteres mange steder fra } \\
\text { Præsentation af teori KAN ske gennem oplæg fra læreren, men det kan også } \\
\text { ske ved at eleverne læser, ser video eller, at eleverne præsenterer teorien for } \\
\text { hinanden. }\end{array}$ \\
\hline $\begin{array}{l}\text { Man skal ikke læse og skrive } \\
\text { i idræt }\end{array}$ & $\begin{array}{l}\text { Man skal også læse og skrive i idræt } \\
\text { Læsning og skrivning i idræt kvalificerer forståelsen og anvendelsen af fagbegre- } \\
\text { ber. Ved at læse tekster bliver eleverne præsenteret for fagbegrebers betydning. } \\
\text { Ved at skrive idrætsfaglige tekster øver eleverne sig i at anvende fagsprog frem } \\
\text { for hverdagssprog. }\end{array}$ \\
\hline $\begin{array}{l}\text { Teori foregår uden bevægel- } \\
\text { se og er kun snak }\end{array}$ & $\begin{array}{l}\text { Teori kan integreres på mange forskellige måder } \\
\text { Idrætsundervisningen skal give eleverne mulighed for at få kropslige, følelses- } \\
\text { mæssige eller sociale erfaringer med de fagbegreber, som er udgangspunkt for } \\
\text { undervisningen. De erfaringer kan danne grundlag for efterfølgende refleksion } \\
\text { og dialog. }\end{array}$ \\
\hline $\begin{array}{l}\text { Teori foregår i et traditio- } \\
\text { nelt klasselokale - også på } \\
\text { læreruddannelsen }\end{array}$ & $\begin{array}{l}\text { Teorien skal integreres i faglokalet } \\
\text { Teorien skal integreres i det rum, hvor den skal anvendes, ellers bliver den } \\
\text { uvedkommende og fremmed for eleverne. Gør hallen til et faglokale ved at lære- } \\
\text { midler, der understøtter brugen af teori, bliver en integreret del af rummet. }\end{array}$ \\
\hline
\end{tabular}

Figur 2: (Mis)forståelser om teori i idrætsundervisningen 
Den indledende praksisfortælling afsluttes med, at Tobias siger til Louise at: "Det er vildt, hvor meget anderledes vores undervisning er nu i forhold til bare for to år siden”. “Ja!” svarer Louise og følger op med: "Det var dælme svært, men nu føles det jo meget nemt. Gad vide hvad vi egentligt gør anderledes?” "Ja det er et godt spørgsmål," siger Tobias.

Det spørgsmål har vi givet et (muligt) svar på med Teoriintegrationsmodellen. Men husk på, at den ikke er en endegyldig sandhed om, hvordan man inddrager teori i idrætsundervisningen. Teoriintegrationsmodellen er et tilbud om handlemuligheder og refleksion over egen undervisning med henblik på løbende at forbedre og variere måden, hvorpå man inddrager teori i idrætsundervisningen.

\section{TAK TIL}

Vi vil gerne sende en STOR tak til de idrætslærerstuderende årgang 2019 i Odense samt Rikke Klokker Grønning og Allan Skoven Pedersen fra Holluf Pile Skole for inspiration til vores teoriintegrationsmodel.

\section{LITTERATURLISTE}

Andkjær, S. (2010). Betydninger af bevægelsesmiljøer i idrætten. FOCUS - Tidsskrift for idræt, 34(4), 6-14.

Bertelsen, K., Bruun, T. H., Halling, A., Hansen, M., \& Knudsen, L. S. (2016). 9. klasse prøve i idræt 2015: en undersøgelse med fremadrettede perspektiv. Forsknings- og Innovationscenter for Idræt, Bevægelse og Læring.

Børne og Undervisningsministeriet (2019). Idræt - Faghæfte 2019.

Christensen, A. B., \& Svendsen, A. M. (2019). (Be)greb om idræt. Meloni.

Christensen, A. B., \& Svendsen, A. M. (Under publicering). (Be)greb om idræt - Indskolingen. Meloni.

Dansk Skoleidræt (2020). Sundhedsdugen.

Engell, C., \& Hansen, T. (2009). Læreprocesser gennem struktureret refleksion. In L. T. Ronglan, G. Teng, \& A. Halling (Eds.), Ballspil over grenser (Vol. 1). Akilles.

EVA, D. E. (2004). Idræt i folkeskolen. https://www.eva.dk/sites/eva/files/2017-10/Idraet_i_folkeskolen.pdf

Gallagher, S. (2017). Enactivist interventions - rethinking the mind. Oxford University Press.

Hansen, T. (2017). Udskolingen I bevægelse: Et aktionsforskningsprojekt med henblik på udvikling af next practice idrætsundervisning Syddansk Universitet]. Odense. 
Hansen, T. I. (2020). Oplevelse, erfaring og erkendelse. In P. Brodersen (Ed.), Didaktisk opslagsbog (pp. 336). Hans Reitzel.

Hedeskov, B., \& Gade, K. (2015). Tjek på idræt (1. udgave). Gyldendal.

Hovgaard, M. (2017). Aktivitetsudvikling i idræt: innovation i praksis (1. udgave). Samfundslitteratur.

Høegh, T. (2018). Mundtlighed og fagdidaktik (1. udgave). Akademisk Forlag.

Høj, B. B., \& Dansk Skoleidræt. (2017). Koordinationstrappen. Dansk Skoleidræt.

Illeris, K. (2015). Læring (3. udgave ed.). Samfundslitteratur.

Knudsen, M. (2017). Lærebøger i skoleidræt - på vej mod "idræt som undervisning"? Forum for Idræt, 32(1). https://doi.org/10.7146/ffi.v32i1.31963

Knudsen, M. E. (2015). Idræt på hjernen: elevhæfte udskoling. University College Syddanmark i samarbejde med Kosmos Nationalt Videncenter.

Knudsen, M. E., \& Seelen, J. v. (2019). Teori i idrætsfaget. In K. Thorgaard \& A. v. Oettingen (Eds.), Universitetsskolen: mellem forskning, uddannelse og skoleudvikling (pp. 219). Dafolo.

Madsen, K. L., \& Aggerholm, K. (2020). ”Den følelse kan jeg ikke skabe, hvis jeg bare står og fortæller" - Lærernes erfaringer med en handlingsorienteret tilgang til bevægelse i folkeskolen. Forskning og Forandring, 3(1), 132-152. https://doi.org/10.23865/fof. v3.2096

Mulvad, R. (2012). Hvorfor fortjener fagtekster særlig opmærksomhed? In M. R. Abildgaard (Ed.), Læsning og skriuning i alle fag (pp. 238). Dafolo.

Oettingen, A. v. (2018). Undervisning er dannelse. Aarhus Universitetsforlag i samarbejde med Danmarks Lærerforening og De Frie Skolers Lærerforening.

Peitersen, B., \& Rønholt, H. (2008). Idrætsundervisning: en grundbog i idrætsdidaktik (Vol. Ny revideret udgave). Institut for Idræt.

Piaster, T. (2020). Teori i idrætsundervisningen med Thomas Piaster In Lyden af idræt. A. B. Christensen.

Piaster, T., Skole OL, \& Dansk Skoleidræt. (2019). Løb, spring og kast-dugen. Dansk Skoleidræt.

Rostbøll, S. F. (2019). Dannelse i idrætsfaget - mere end kropslige kompetencer. In M. W. Andersen (Ed.), Dannelse i alle fag (pp. 246). Dafolo.

Seelen, J. v., Guldager, J. D., Bruun, T. H., Knudsen, M. E., \& Berthelsen, K. (2018). Status på idrætsfaget 2018

Seelen, J. v., \& Munk, M. (2012). Status på Idrætsfaget. https://vicekosmos.dk/fileadmin/user_upload/KOSMOS/Gamle_filer/fileadmin/user_upload/publikationer/ SPIF-RAPPORT_e-version.pdf

Svendsen, A. M. (2012). Idræt (1. udgave ed.). Klim i samarbejde med Læremiddel.dk. 
Svendsen, A. M., \& Dansk Skoleidræt. (2018). Danserammen.

Thingholm, H. B. (2020). Didaktiske forståelsesdialoger (C. H. Rickmann \& L. Rindholt, Trans.). In O. Dysthe, I. J. Ness, \& P. O. Kirkegaard (Eds.), Dialogisk pædagogik, kreativitet og læring (pp. 386). Klim. 